Phosphodi est er ase 4 i nhi bi tor rol i pram potenti ates the i nhi bi tory effect of cal ci toni $\mathrm{n}$ on ost eocl ast ogenesi s

\begin{tabular}{|l|l|}
\hline 著者 & $\begin{array}{l}\text { M yantot o Keni chi , N shi oka Tat suo, Waki } \\
\text { Yoshi hi ro }\end{array}$ \\
\hline $\begin{array}{l}\text { j our nal or } \\
\text { publ i cat i on ti t l e }\end{array}$ & Journal of Bone and M ner al Net abol i sm \\
\hline vol une & 24 \\
\hline number & 4 \\
\hline page r ange & $260-265$ \\
\hline year & $2006-07-01$ \\
\hline URL & ht t p: //hdl . handl e. net /2297/2957 \\
\hline
\end{tabular}




\section{Phosphodiesterase 4 inhibitor rolipram potentiates the inhibitory effect of calcitonin on osteoclastogenesis}

Received: June 3, 2005 / Accepted: February 8, 2006

\begin{abstract}
To assess the combination effect of calcitonin and the phosphodiesterase 4 inhibitor rolipram on osteoclastogenesis, adherent cell-depleted bone marrow cells from mouse tibia and femur (ACD-BMCs), which were cultured in the presence of $25 \mathrm{ng} / \mathrm{ml}$ colony-stimulating factor $1(\mathrm{CSF}-1)$ and $100 \mathrm{ng} / \mathrm{ml}$ soluble receptor activator of $\mathrm{NF}-\kappa \mathrm{B}$ ligand (sRANKL), were utilized. Calcitonin inhibited formation of tartrate-resistant acid phosphatasepositive multinucleated cells, as mature osteoclasts, by $70 \%$ even at $20 \mathrm{pM}$, whereas rolipram $(10 \mu \mathrm{M})$ scarcely affected osteoclast formation; in contrast, the combination of both agents led to significant inhibition of multinucleation and pit formation ability of osteoclasts. The combined administration of calcitonin and rolipram attenuated calcitonin receptor mRNA expression in comparison to treatment with either agent alone, whereas expression of RANK and CSF1 receptor mRNAs was unchanged. Alone, these agents scarcely elevated intracellular cyclic AMP (cAMP) concentration; however, combination treatment with both agents significantly increased cAMP concentration in osteoclast
\end{abstract}

K. Miyamoto $(\triangle) \cdot \mathrm{K}$. Yokogawa

Department of Hospital Pharmacy, School of Medicine, Kanazawa

University, 13-1 Takara-machi, Kanazawa 920-8641, Japan

Tel. +81-76-265-2045; Fax. +81-76-234-4280

e-mail: miyaken@pharmacy.m.kanazawa-u.ac.jp

K. Miyamoto $\cdot$ T. Nishioka $\cdot$ M. Nomura $\cdot$ K. Yokogawa

Department of Clinical Pharmacy, Graduate School of Natural

Science and Technology, Kanazawa University, Kanazawa, Japan

Y. Waki

Department of Pharmacology and Pharmacotherapy, Nihon

Pharmaceutical University, Saitama, Japan

M. Nomura

Department of Clinical Pharmacology, Faculty of Pharmaceutical

Sciences, Hokuriku University, Kanazawa, Japan

H. Katsuta

Examination Research Section, SCG, Inc., Tokyo, Japan

H. Amano

Department of Pharmacology, School of Dentistry, Showa

University, Tokyo, Japan progenitors and osteoclasts. The combination effect was abolished by $\mathrm{H}-89$, an inhibitor of protein kinase A. It appears that rolipram inhibited hydrolysis of cAMP formed by calcitonin in cells and potentiated the inhibitory effect of calcitonin on osteoclastogenesis. The escape phenomenon following calcitonin treatment may also be prevented by concomitant treatment with the phosphodiesterase 4 inhibitor.

Key words calcitonin - phosphodiesterase 4 rolipram · bone marrow cells · osteoclastogenesis

\section{Introduction}

The signal pathways of parathyroid hormone and calcitonin (CT), which regulate calcium metabolism, involve cyclic AMP (cAMP) as an intracellular second messenger following stimulation of the receptors on osteoblasts and osteoclasts, respectively [1]. Therefore, inhibition of hydrolysis of cAMP produced in response to these hormones is expected to potentiate the action of these hormones on bone cells. Cyclic nucleotide phosphodiesterase (PDE) is classified into 11 isoenzyme families, which differ in their substrate specificity, affinity for cyclic nucleotides, and regulatory properties [2-5]. Among these families, PDE 4 isoenzyme is a cAMP-specific PDE; furthermore, its inhibitors display selective bronchodilator activity [6,7] and antiinflammatory action [8]. Moreover, we recently reported that among PDE inhibitors the PDE 4 inhibitor specifically increased osteoblast formation and decreased osteoclast formation in in vitro bone marrow culture; additionally, we identified a therapeutic effect of PDE 4 inhibitors against bone loss in some animal osteopenia models $[9,10]$. We also indicated that the effects of PDE 4 inhibitors on osteoblast and osteoclast formation synergistically inhibit hydrolysis of cAMP in the progenitor cells produced by prostaglandin $\mathrm{E}_{2}\left(\mathrm{PGE}_{2}\right)$ secreted by bone marrow stromal cells $[11,12]$.

Osteoclast progenitor cells are stimulated and their maturation is promoted via membrane interaction with 
osteoblasts/stromal cells through the receptor activator of nuclear factor $\kappa \mathrm{B}$ (RANK), which is a receptor activator of the nuclear factor $\kappa B$ ligand (RANKL) system $[13,14]$. Osteoclast formation and maturation are promoted by a production ratio of RANKL versus osteoprotegerin (OPG; a decoy receptor for RANKL secreted by stromal cells; also referred to as osteoclastogenesis inhibitory factor, OCIF) following stimulation of osteoblastic stromal cells by osteotropic factors such as 1 1 ,25-dihydroxyvitamin $\mathrm{D}_{3}\left(1,25(\mathrm{OH})_{2} \mathrm{D}_{3}\right)$, para thyroid hormone $(\mathrm{PTH})$, or interleukin 11 (IL-11) [15,16]. Therefore, osteoclastogenesis is regulated by interaction with stromal cells and stimulation involving several osteotropic factors. On the other hand, it is well known that CT directly inhibits osteoclast formation and its bone resorption activity [17-19].

This study examined the direct effect of CT on osteoclastogenesis and the combination effect of the PDE 4 inhibitor rolipram employing adherent cell-depleted bone marrow cells from mouse tibia and femur (ACD-BMCs), which were cultured in the presence of $25 \mathrm{ng} / \mathrm{ml}$ colonystimulating factor 1 (CSF-1, or M-CSF) and $100 \mathrm{ng} / \mathrm{ml}$ soluble RANKL (sRANKL).

\section{Methods}

Materials and animals

Rolipram (Wako, Osaka, Japan), naphthol AS-MX phosphate sodium, fast red violet LB salt (Sigma, St. Louis, MO, USA), salmon calcitonin (CT; Bachem Feinchemikalien, Bubendorf, Switzerland), and $N-[2-(p-$ bromocinnamylamino)ethyl]-5-isoquinoline-sulfonamide (H-89; Seikagaku Kogyo, Tokyo, Japan) were purchased from the respective commercial sources. Recombinant human CSF-1 and recombinant human sRANKL were acquired from PeproTech (London, England). Male ddY mice (8 weeks of age; Nippon SLC, Hamamatsu, Japan) were used randomly in this study.

\section{Preparation of ACD-BMCs}

Suspensions $(2 \mathrm{ml})$ of bone marrow cells obtained from mouse tibiae and femurs were gently introduced into the Sephadex G-10 (Amersham Pharmacia Biotech, Bucks, U.K.) column system according to the method of Ly and Mishell [20]. Cells were infiltrated with the carrier; subsequently, the cell suspension was introduced to $8 \mathrm{ml}$ of the medium, followed by incubation at $37^{\circ} \mathrm{C}$ for $45 \mathrm{~min}$. Next, the eluted suspension of nonadherent bone marrow cells was collected and used as ACD-BMCs.

\section{Primary culture of ACD-BMCs}

According to a method described by Niida et al. [21], ACDBMCs were cultured to generate osteoclasts. Wells of 96well plates were coated with $5 \mu$ l of a solution containing
$625 \mathrm{ng} / \mathrm{ml} \mathrm{CSF}-1$ and $2.5 \mu \mathrm{g} / \mathrm{ml}$ sRANKL in fetal bovine serum (FBS) and dried for $1 \mathrm{~h}$ on a clean bench. The ACDBMCs were prepared for $1.5 \times 10^{6}$ cells $/ \mathrm{ml}$ with alphaminimum essential medium ( $\alpha-\mathrm{MEM})(\mathrm{pH} 7.0)$ containing $15 \%$ FBS; subsequently, cell suspensions $(125 \mu 1 /$ well $)$ were seeded into 96-well plates. At 3 days after culture, the medium was changed to $\alpha$-MEM containing $15 \%$ FBS, $25 \mathrm{ng} / \mathrm{ml} \mathrm{CSF}-1$, and $100 \mathrm{ng} / \mathrm{ml}$ sRANKL in the presence or absence of calcitonin and rolipram. The treatment was conducted for 2 days, after which cultures were fixed and stained in $0.1 \mathrm{mg} / \mathrm{ml}$ naphthol AS-MX phosphate sodium, $0.6 \mathrm{mg} / \mathrm{ml}$ fast red violet LB salt, and $50 \mathrm{mM}$ sodium tartrate $/ 0.1 \mathrm{M}$ sodium acetate $(\mathrm{pH}$ 5.0) for tartrate-resistant acid phosphatase (TRAP). Samples were washed with distilled water, dried, and observed under a light microscope. Those cells positive for TRAP and exhibiting more than three nuclei were counted as mature ostoclasts.

The absence of stromal cells or osteoblast progenitors in the cell population was confirmed from bone-type alkaline phosphatase (ALP) mRNA expression. Moreover, ALPpositive cells or nodules were never observed as a result of treatment with or without rolipram under these conditions, whereas PDE 4 inhibitors, including rolipram, exerted an osteoblastogenic action on stromal or bone marrow cells [9-11].

Pit assay

ACD-BMCs were plated on dentine slices and cultured in $\alpha$-MEM containing $15 \%$ FBS, $25 \mathrm{ng} / \mathrm{ml} \mathrm{CSF-1,} \mathrm{and}$ $100 \mathrm{ng} / \mathrm{ml}$ sRANKL for 6 days [22]. Further incubation consisted of 48-h treatment of cells on the slices in the presence or absence of calcitonin and rolipram. After culture, the slices were treated with $0.05 \mathrm{M}$ ammonium hydroxide for $30 \mathrm{~min}$, and cells were removed from the dentine slices. Backscattered electron images of the dentine slices were examined with a Hitachi S-2500CX scanning electron microscope [23].

Reverse transcription-polymerase chain reaction assay

mRNAs were prepared from cultures utilizing a QuickPrep micro mRNA purification kit (Pharmacia Biotech, Uppsala, Sweden). Synthesis of cDNA from isolated mRNA was conducted with RNase H-reverse transcriptase and analyzed for expression of mouse RANK, CSF-1 receptor (CSF-1R), and calcitonin receptor (CT-R) transcripts by reverse transcription-polymerase chain reaction (RT-PCR). RT-PCR was performed using primers per details described previously for $\beta$-actin [24]. Primers for mouse RANK were 5'-GCTTGCTGCATAAAGTCTG-T-3' and 5'-ACGT CCTAGAATCTCTGACT-3' (708bp); primers for mouse CSF-1 receptor were 5'-AACAAGTTCTACAAACTGGT GAAGG-3' and 5'-GAAGCCTGTAGTCTAAGCATC TGTC-3' (752 bp); primers for mouse calcitonin receptor were $5^{\prime}$-AGAATTCCTGCATCCACCTA- $3^{\prime}$ and 5'TGAAAGCGTTGCACAGAGTA-3' (558 bp) (cited from GenBank sequence database); and primers for $\beta$-actin were 
5'-TTCTACAATGAGCTGCGTGTGGC- $3^{\prime}$ and 5'CTC(A/G)TAGCTCTTCTCCAGGGAGGA-3' (456bp), as reported by Waki et al. [24].

\section{Measurement of cyclic AMP}

Intracellular cyclic AMP (cAMP) was measured with a cAMP EIA system (Amersham International, Little Chalfont, U.K.).

\section{Data analysis}

Data were analyzed using Student's $t$ test to compare the unpaired means of two sets of data. A $P$ value of 0.05 indicated a significant difference between sets of data.

\section{Results}

Effect on osteoclast formation in culture of ACD-BMCs

ACD-BMCs were treated with CT $(2-20 \mathrm{pM})$ and/or rolipram $(10 \mu \mathrm{M})$ in the presence of $25 \mathrm{ng} / \mathrm{ml}$ CSF-1 and $100 \mathrm{ng} / \mathrm{ml}$ sRANKL; subsequently, the number of TRAP-positive MNCs was counted. As shown in Fig. 1, CT reduced the number of TRAP-positive MNCs by approximately $70 \%$ even at $20 \mathrm{pM}$; furthermore, rolipram $(10 \mu \mathrm{M})$ alone also inhibited MNC formation somewhat. However, rolipram synergistically potentiated the inhibitory effect of CT on osteoclast formation. Figure 1 also exhibits abolition of the combination effect by an inhibitor of protein kinase A, H-89 $(10 \mu \mathrm{M})$.

Following combined treatment with $\mathrm{CT}(10 \mathrm{pM})$ and rolipram $(10 \mu \mathrm{M})$, DNA content in the culture was unchanged (data not shown). In addition, numerous TRAPpositive mononuclear cells were present in the culture, although TRAP-positive MNCs were observed after CT administration alone (Fig. 2).

Figure 3 illustrates the pit formation ability of osteoclasts after treatment with CT $(10 \mathrm{pM})$ and rolipram $(10 \mu \mathrm{M})$. Many lacunae were formed on the dentine slice of untreated controls and on samples treated with calcitonin alone; in contrast, combination treatment involving $\mathrm{CT}$ and rolipram abolished both osteoclast formation and lacunae resorption.

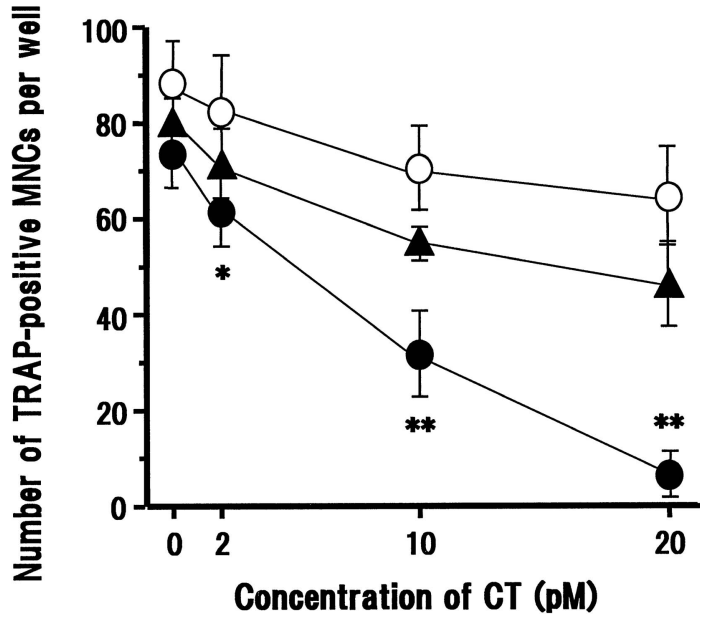

Fig. 1. Effect of rolipram on formation of tartrate-resistant acid phosphatase (TRAP)-positive multinucleated cells (MNCs) in adherent cell-depleted bone marrow cells (ACD-BMCs). Cells were cultured with $25 \mathrm{ng} / \mathrm{ml}$ colony-stimulating factor 1 (CSF-1) and $100 \mathrm{ng} / \mathrm{ml}$ soluble receptor activator of NF- $\mathrm{KB}$ ligand (sRANKL) (osteoclastogenesis conditions) for 5 days and the indicated concentrations of calcitonin (CT) in the absence or presence of $10 \mu \mathrm{M}$ rolipram and/or $10 \mu \mathrm{M} \mathrm{H}-89$ for the final 2 days. After culture, cells were fixed and stained for TRAP. O, CT alone; $\bullet$ CT plus rolipram; $\boldsymbol{\Delta}$, CT plus rolipram plus $\mathrm{H}$ 89. Each value is the mean \pm SD of six experiments. *** Significantly different from the CT-only cultures at $P<0.05$ and 0.01 , respectively
Fig. 2. Phase-contrast micrographs of ACD-BMC cultures. Cells were cultured with $10 \mathrm{pM}$ CT with (left) or without (right) $10 \mu \mathrm{M}$ rolipram under osteoclastogenesis conditions. After culture for 5 days, cells were fixed and stained for TRAP
CT (10 pM) alone

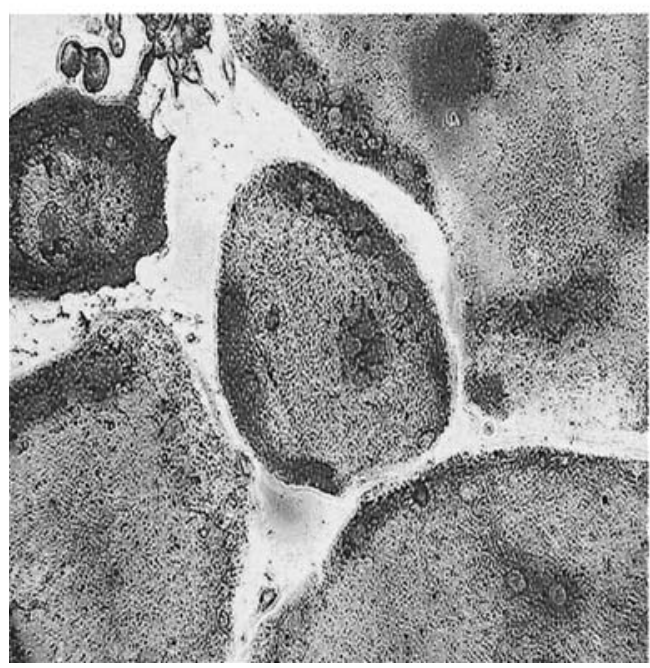

CT (10 pM) + Rolipram $(10 \mu \mathrm{M})$

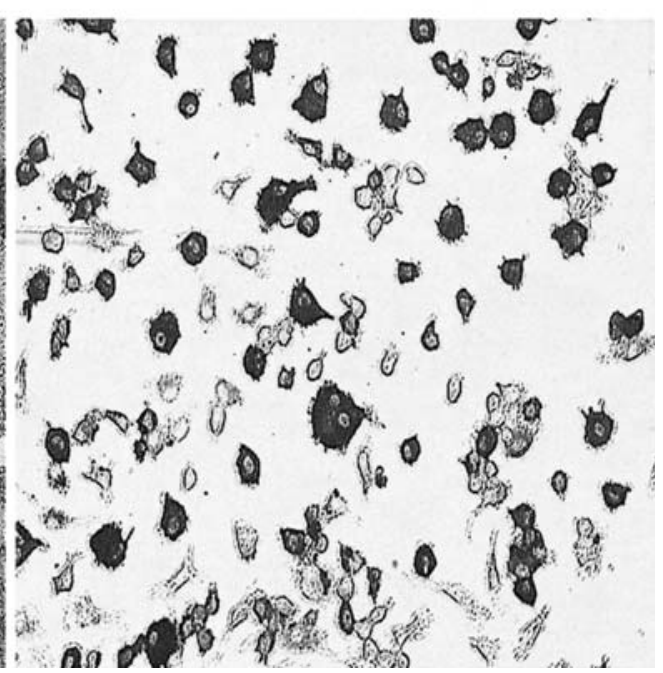


Fig. 3. Scanning electron micrographs of dentine slice cultured with ACD-BMCs. ACD-BMCs were cultured on a dentine slice with $25 \mathrm{ng} / \mathrm{ml}$ CSF-1, $100 \mathrm{ng} / \mathrm{ml}$ sRANKL, and $10 \mathrm{pM}$ CT with (left) or without (right) $10 \mu \mathrm{M}$ rolipram. Backscattered electron images of dentine slices are presented
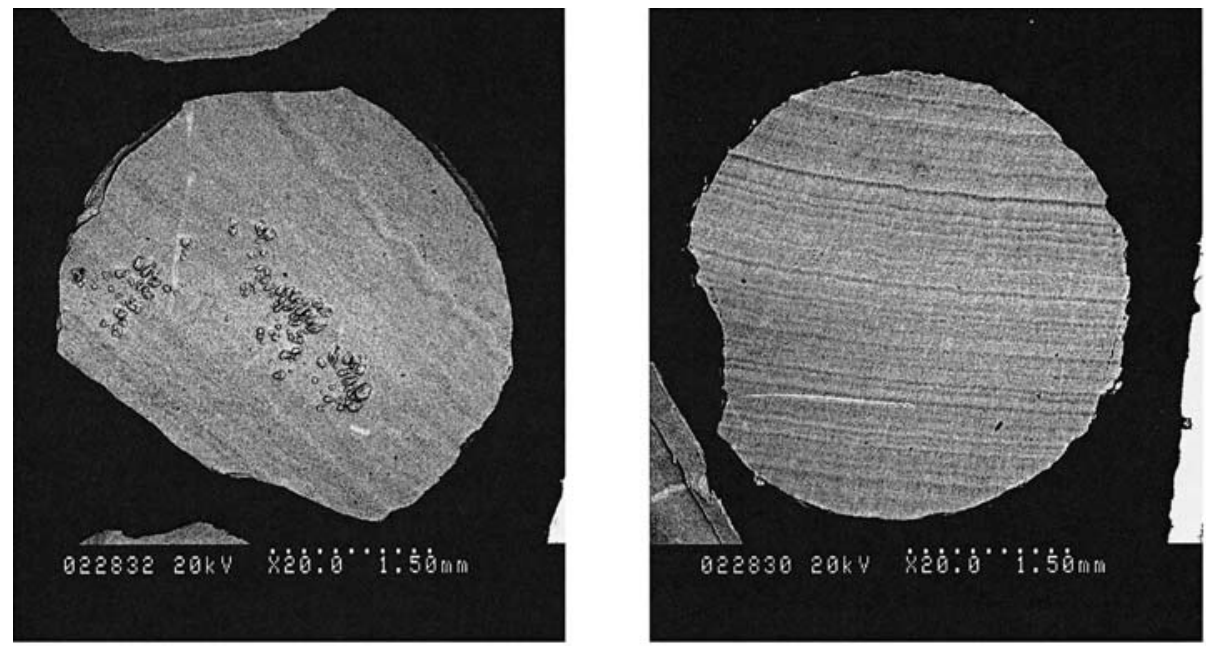

\section{CT $(10 \mathrm{pM})$ alone $\quad$ CT $(10 \mathrm{pM})+$ Rolipram $(10 \mu \mathrm{M})$}
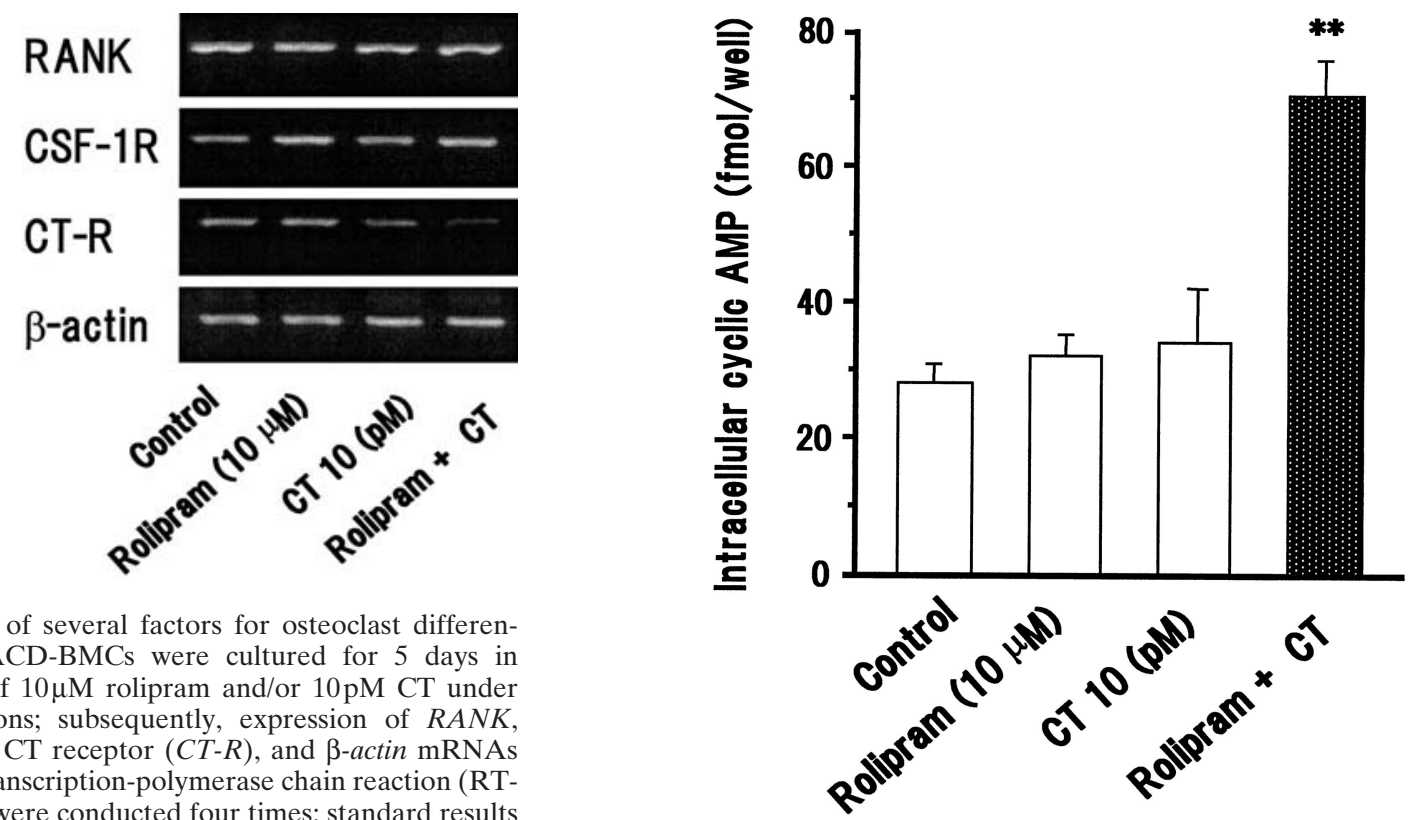

Fig. 4. mRNA expression of several factors for osteoclast differentiation in ACD-BMCs. ACD-BMCs were cultured for 5 days in the absence or presence of $10 \mu \mathrm{M}$ rolipram and/or $10 \mathrm{pM}$ CT under osteoclastogenesis conditions; subsequently, expression of RANK, CSF-1 receptor $(C S F-1 R)$, CT receptor $(C T-R)$, and $\beta$-actin mRNAs was analyzed via reverse transcription-polymerase chain reaction (RTPCR). These experiments were conducted four times; standard results are represented

Analysis of mRNA expression

mRNAs of RANK and CSF-1R in ACD-BMCs were expressed from the early stage of culture with sRANKL and CSF-1; however, expression of CT-R mRNA increased with the culture period and maturation of osteoclasts [12]. CT $(10 \mathrm{pM})$ slightly inhibited expression of CT-R mRNA, but not that of RANK and CSF-1R mRNAs; furthermore, expression of CT-R mRNA was markedly decreased upon combination with rolipram $(10 \mu \mathrm{M})$, which scarcely altered the expression of these mRNAs alone (Fig. 4).

\section{Effect on intracellular cAMP concentration in osteoclasts}

CT $(10 \mathrm{pM})$ and/or rolipram $(10 \mu \mathrm{M})$ were introduced to osteoclasts, and intracellular cAMP concentration was measured for $1 \mathrm{~h}$. Figure 5 demonstrates that intracellular cAMP concentration was little changed following addition of CT or rolipram alone; in contrast, cAMP levels increased significantly following combined treatment with $\mathrm{CT}$ and rolipram. 


\section{Discussion}

When ACD-BMCs were cultured in the presence of $25 \mathrm{ng} / \mathrm{ml} \mathrm{CSF}-1$ and $100 \mathrm{ng} / \mathrm{ml} \mathrm{sRANKL}$ for 5 days to mature osteoclasts, the inhibitory effects of CT on osteoclast multinucleation and pit formation were synergistically potentiated by combination with the PDE 4 inhibitor rolipram (see Figs. 1-3). We previously reported that expression of PDE 4 isoenzyme among some PDE isoenzymes increased during culture of rat BMCs [11] and that the PDE 4 inhibitors enhanced osteoblastogenesis and diminished osteoclastogenesis, resulting in a therapeutic effect against bone loss in some animal osteopenia models $[9,10]$. Furthermore, we indicated that PDE 4 inhibitors promote osteoblast formation and inhibit osteoclast formation via enhancement of the action of cAMP in their progenitor cells produced by endogenous prostaglandin $\mathrm{E}_{2}\left(\mathrm{PGE}_{2}\right)$ $[11,12]$. Thus, the $\mathrm{PGE}_{2}$ receptors are expressed on the plasma membrane of both osteoblasts and osteoclasts, but the signal pathways of parathyroid hormone and CT involve cAMP as an intracellular second messenger after stimulation of their receptors on osteoblasts and osteoclasts, respectively [1]. Therefore, PDE 4 inhibitors may exert a complex influence on bone metabolism in vivo.

This investigation confirmed that the PDE 4 inhibitor rolipram potentiates the inhibitory effect of CT on osteoclastogenesis through cAMP production in osteoclast progenitors. It has been reported that $\mathrm{CT}$ immobilizes and contracts osteoclasts away from the bone surface through the action of cAMP enhanced because of stimulation of CT$\mathrm{R}$ [25]; however, osteoclasts continuously exposed to CT can escape the effects of CT as a result of rapid profound reduction in CT-R mRNA expression [26]. In this study, following 5-day CT exposure, its effect appeared to be weak (see Figs. 1, 3); however, it inhibited the expression of CTR mRNA but not that of RANK or of CSF-1R mRNAs (see Fig. 4). These results may indicate the escape phenomena of osteoclasts from CT. On the other hand, in combination with rolipram, the number, particularly in the case of multinuclear cells, and the function of osteoclasts were significantly attenuated; additionally, CT-R expression decreased further. These findings suggest that addition of a PDE 4 inhibitor during CT treatment prevents the escape phenomena with respect to CT and inhibits osteoclastogenesis through the action of elevated cAMP in osteoclast progenitors.

Recently, several PDE 4 inhibitors have been developed for asthma and chronic obstructive pulmonary disease and have proceeded to late-phase clinical trial [27], although rolipram cannot be used because of its severe side effects, such as emesis [28]. Therefore, novel PDE 4 inhibitor drugs may be candidates for osteoporosis therapy consequent to their anabolic actions and potentiation of CT action.

\section{References}

1. Kent GN, Jilka RL, Cohn DV (1980) Homologous and heterologous control of bone cell adenosine $3^{\prime}, 5^{\prime}$-monophosphate response to hormones by parathormone, prostaglandin $\mathrm{E}_{2}$, calcitonin, and 1,25-dihydroxycholecalciferol. Endocrinology 107:1474-1481

2. Beavo JA (1995) Cyclic nucleotide phosphodiesterases; functional implications of multiple isoforms. Physiol Rev 75:725-748

3. Conti M, Nemoz G, Sette C, Vicini E (1995) Recent progress in understanding the hormonal regulation of phosphodiesterases. Endocrine Rev 16:370-389

4. Soderling SH, Bayuga SJ, Beavo JA (1998) Cloning and characterization of a cAMP-specific cyclic nucleotide phosphodiesterase. Proc Natl Acad Sci USA 95:8991-8996

5. Fisher DA, Smith JF, Pillar JS, St. Denis SH, Cheng JB (1998) Isolation and characterization of PDE 9A, a novel human cGMPspecific phosphodiesterase. J Biol Chem 273:15559-15564

6. Polson JB, Krzanowski JJ, Szentivanyi A (1982) Inhibition of high affinity cyclic AMP phosphodiesterase and relaxation of canine tracheal smooth muscle. Biochem Pharmacol 31:3404-3406

7. Miyamoto K, Kurita M, Ohmae S, Sakai R, Sanae F, Takagi K (1994) Selective tracheal relaxation and phosphodiesterase-IV inhibition by xanthine derivatives. Eur J Pharmacol 267:317-322

8. Semmler J, Wachtel H, Endres S (1993) The specific type IV phosphodiesterase inhibitor rolipram suppress TNF $\alpha$ production by human mononuclear cells. Int J Immunopharmacol 15:409413

9. Miyamoto K, Waki Y, Horita T, Kasugai S, Ohya K (1997) Reduction of bone loss by denbufylline, an inhibitor of phosphodiesterase 4. Biochem Pharmacol 54:613-617

10. Waki Y, Horita T, Miyamoto K, Ohya K, Kasugai S (1999) Effects of XT-44, a phosphodiesterase 4 inhibitor, in osteoblastogenesis and osteoclastogenesis in culture and its therapeutic effects in rat osteopenia models. Jpn J Pharmacol 79:477-483

11. Miyamoto K, Suzuki H, Yamamoto S, Saitoh Y, Ochiai E, Mritani S, Yokogawa K, Waki Y, Kasugai S, Sawanishi H, Yamagami H (2003) Prostagladin $\mathrm{E}_{2}$-mediated anabolic effect of a novel inhibitor of phosphodiesterase 4, XT-611, in the in vitro bone marrow culture. J Bone Miner Res 18:1471-1477

12. Yamagami H, Nishioka T, Ochiai E, Fukushima K, Nomura M, Kasugai S, Moritani S, Yokogawa K, Miyamoto K (2003) Inhibition of osteoclastogenesis by a phosphodiesterase 4 inhibitor XT611 through synergistic action with endogenous prostaglandin $E_{2}$. Biochem Pharmacol 66:801-807

13. Anderson DM, Maraskovsky E, Billingsley WL, Dougall WC, Tometsko ME, Roux ER, Teepe MC, Dubose RF, Cosman D, Galibert L (1997) A homologue of the TNF receptor and its ligand enhance T-cell growth and dendritic-cell function. Nature (Lond) 390:175-179

14. Yasuda H, Shima N, Nakagawa N, Yamaguchi K, Kinosaki M, Mochizuki S, Tomoyasu A, Yano K, Goto M, Murakami A, Tsuda E, Morinaga T, Higashio K, Udagawa N, Takahashi N, Suda T (1998) Osteoclast differentation factor is a ligand for osteoprotegerin/osteoclastogenesis-inhibitory factor and its identical to TRANCE/RANKL. Proc Natl Acad Sci USA 95:3597-3602

15. Horwood NJ, Elliott J, Martin TJ, Gillespie MT (1998) Osteotropic agents regulate the expression of osteoclast differentiation factor and osteoprotegerin in osteoblastic stromal cells. Endocrinology 139:4743-4746

16. Nagai M, Sato N (1999) Reciprocal gene expression of osteoclastogenesis inhibitory factor and osteoclast differentiation factor regulates osteoclast formation. Biochem Biophys Res Commun 257:719-723

17. Hata K, Kukita T, Akamine A, Kukita A, Kurisu K (1992) Trypsinized osteoclast-like multinucleated cells formed in rat bone marrow cultures efficiently form resorption lacunae on dentine. Bone (NY) 13:139-146

18. Mano M, Arakawa $T$, Nakagawa $M$, Kaneda $T$, Kaneko $H$, Yamada T, Miyata K, Kiyomura H, Kumegawa H, Hakeda Y (2000) Prostaglandin $E_{2}$ directly inhibits bone-resorbing activity of isolated mature osteoclasts mainly through EP4 receptor. Calcif Tissue Int 67:85-92

19. Takahashi N, Yamana H, Yoshiki S, Roodman GD, Mundy GR, Jones SJ, Boyde A, Suda T (1988) Osteoclast-like cell formation 
and its regulation by osteotropic hormones in mouse bone marrow cutures. Endocrinology 122:1373-1382

20. Ly IA, Mishell RI (1974) Separation of mouse spleen cells by passage through column of Sephadex G-10. J Immunol Methods 5:239-247

21. Niida S, Kaku M, Amano H, Yoshida H, Kataoka H, Nishikawa S, Tanne K, Maeda N, Nishikawa S, Kodama H (1999) Vascular endotherial growth factor can substitute for macrophage colonystimulating factor in the support of osteoclastic bone resorption. $\mathrm{J}$ Exp Med 190:293-298

22. Matsuo K, Galson DL, Zhao C, Peng L, Laplace C, Wang KZ, Bachler MA, Amano H, Aburatani H, Ishikawa H, Wagner EF (2004) Nuclear factor of activated T-cells (NFAT) rescues osteoclastogenesis in precursors lacking c-Fos. J Biol Chem 279:26475-26480.

23. Amano H, Yamada S, Felix R (1998) Colony-stimulating factor-1 stimulates the fusion process in osteoclasts. J Bone Miner Res 13:846-853

24. Waki Y, Miyamoto K, Kasugai S, Ohya K (1995) Osteoporosis-like changes in Walker carcinoma 256-bearing rats, not accompanied with hypercalcemia or parathyroid hormone-related protein production. Jpn J Cancer Res 86:470-476

25. Gorn AH, Rudolph SM, Flannery MR, Morton CC, Weremowicz S, Wang TZ, Krane SM, Goldring SR (1995) Expression of two human skeletal calcitonin receptor isoforms cloned from a giant cell tumor of bone. The first intracellular domain modulates ligand binding and signal transduction. J Clin Invest 95:26802691

26. Wada S, Udagawa N, Akatsu T, Nagata N, Martin TJ, Findlay DM (1997) Regulation by calcitonin and glucocorticoids of calcitonin receptor gene expression in mouse osteoclasts. Endocrinology 138:521-529

27. Lipworth BJ (2005) Phosphodiesterase-4 inhibitors for asthma and chronic obstructive pulmonary disease. Lancet 365:167-175

28. Duplantier AJ, Biggers MS, Chambers RJ, Cheng JB, Cooper K, Damon DB, Eggler JF, Kraus KG, Marfat A, Masamune H, Pillar JS, Shirley JT, Umland JP, Watson JW (1996) Biarylcarboxylic acids and - amides: inhibition of phosphodiesterase type IV versus $\left[{ }^{3} \mathrm{H}\right]$ rolipram binding activity and their relationship to emetic behavior in the ferret. J Med Chem 39:120-125 